\title{
INDONESIA DAN ANCAMAN TERORISME: DALAM ANALISIS DIMENSI IMATERIAL
}

\author{
Ardli Johan Kusuma, Tulus Warsito, Surwandono, dan Ali Muhammad \\ Program Doktoral Politik Islam - Ilmu Politik, Universitas Muhammadiyah Yogyakarta, Indonesia, \\ J1. Brawijaya, Bantul, Yogyakarta 55183, Indonesia. \\ E-mail: ardli.johan@yahoo.com
}

\begin{abstract}
ABSTRAK. Pasca peristiwa 9/11, isu terorisme di dunia internasional menjadi isu penting. Bahkan di Indonesia pasca peristiwa serangan terhadap gedung WTC tersebut direspon dengan membuat instrumen kontra treorisme dalam konteks nasional yang kemudian dalam proses pelaksanaannya dianggap melanggar HAM. Padahal fenomena terorisme di Indonesia sebenarnya sudah ada jauh sebelum Indonesia membuat kebijakan-kebijakan kontra terorisme seperti: pembuatan UU anti terorisme, pembentukan BNPT, serta pembentukan pasukan khusus Densus 88 . Tulisan ini ingin menjelaskan adanya pengaruh dari dimensi ide yang mempengaruhi persepsi pemerintah Indonesia dalam memaknai ancaman terorisme yang dibangun dalam konteks konstruksi sosial dalam pergaulan internasional, yang kemudian memberikan pengaruh bagi pemerintah Indonesia untuk membuat kebijakan represif dan cenderung melanggar HAM dalam kontra terorisme karena terorisme dipersepsikan sebagai ancaman nasional yang luar biasa.
\end{abstract}

Kata kunci: Terorisme; Keamanan Nasional; Ide; Persepsi

\section{INDONESIA AND THE THREAT OF TERRORISM: IN THE ANALYSIS OF THE IMATERIAL DIMENSIONS}

\begin{abstract}
After the 9/11 incident, the issue of terrorism in the international world became an important issue. Even in Indonesia after the attack on the WTC building, it was responded by making counter-terrorism instruments in the national context which were later considered as violating human rights. Even though the phenomenon of terrorism in Indonesia actually existed long before Indonesia made counter-terrorism policies such as: the making of anti-terrorism laws, the establishment of BNPT, and the formation of special forces Detachment 88. This paper wants to explain the influence of ideas that influence the Indonesian government's perception the threat of terrorism that is built in the context of social construction in international relations, which then gives an influence to the Indonesian government to make repressive policies and tend to violate human rights in counter-terrorism because terrorism is perceived as an extraordinary national threat.
\end{abstract}

Keywords: Terrorism; National Security; Ideas; Perception

\section{PENDAHULUAN}

Setelah tahun 2000-an, salah satu ancaman yang menjadi perhatian negara-negara di dunia internasional adalah ancaman aksi terorisme. Berbagai aksi terorisme yang terjadi di dunia membuat masyarakat internasional memandang serius masalah terkait terorisme, meskipun pada dasarnya fenomena terorisme sudah ada sejak lama. Pemaknaan ancaman yang diakibatkan oleh terorisme tidak terlepas dari konstruksi sosial yang terjadi dalam dunia internasional, sehingga hampir setiap negara di dunia memberikan label teroris kepada kelompok tertentu yang kemudian dimaknai sebagai ancaman terhadap kemanusiaan (Hülsse \& Spencer, 2008). Salah satu pemicu perkembangan tersebut adalah terjadinya aksi teror di Amerika Serikat pada tahun 2001, dimana waktu itu gedung WTC menjadi sasaran teror.

Teror yang terjadi di gedung WTC pada 11 September 2001, menjadikan dunia internasional semakin gencar melawan terorisme, bahkan aksi terorisme dianggap sebagai suatu aksi kejahatan terhadap kemanusiaan (crime against humanity). Tindak pidana terorisme dianggap sebagai kejahatan yang luar biasa atau extraordinary crime, maka dari itu diperlukan instrumen khusus untuk menanggulangi kejahatan yang dianggap tidak biasa ini.
Pemaknaan atas kejahatan terorisme yang dianggap sebagai tindakan kejahatan luar biasa, pertama kali dimunculkan dalam forum PBB ketika diadakan kongres di Wina Austria, pada Tahun 2000, dimana saat itu tema yang diambil adalah "The Prevention of Crime and The Treatment of Offenders". Untuk itu banyak negara di dunia termasuk Indonesia, merasa perlu membuat suatu perlakuan khusus terhadap aksi-aksi penyerangan yang masuk kedalam kriteria terorisme (Muhtar, 2014).

Dalam menanggapi ancaman terorisme, pemerintah Indonesia telah merespon dengan beberapa kebijakan, diantaranya pemerintah membuat UU anti terorisme pada tahun 2003 yang kemudian diamandemen pada tahun 2018, kemudian pemerintah juga membentuk BNPT sebagai badan nasional yang khusus menangani masalah terorisme. selain itu pemerintah Indonesia juga telah membentuk pasukan khusus yang terjun langsung di lapangan guna menangani masalah terorisme tersebut. Pemerintah melalui POLRI, membentuk pasukan Detasemen Khusus 88 (Densus 88), yang memiliki kewenangan yang cukup besar. Kewenangan dari Densus 88 diantaranya adalah diperbolehkan untuk melakukan penangkapan, terhadap para terduga teroris, meskipun hanya berbekal bukti awal yang bersumber dari laporan intelijen. Selain itu Densus 
88 juga dapat melakukan penangkapan terhadap terduga teroris selama 7 x 24 jam yang dikenal sebagai "AntiTerrorism Act". Lama penangkapan terhadap terduga teroris ini lebih lama dibandingkan dengan penagkapat terhadap pelanggar hukum pidana selain terorisme.

Selanjutnya dalam pelaksanaan kebijakan yang telah dibuat untuk menanggapi ancaman terorisme tersebut, Indonesia cenderung menggunakan pendekatan yang represif. Densus 88 yang dibentuk sebagai pasukan anti teror di bawah naungan POLRI, lebih banyak menggunakan pendekatan yang bersifat menekan dalam menangani para terduga teroris. Hal ini dapat dilihat ketika densus 88 seringkali melakukan penggerebekan atau penyerangan terhadap para teroris di tempat persembunyian atau markas mereka dengan menggunakan pendekatan kekerasan, bahkan tidak jarang penangkapan terduga teroris berujung pada kematian dan tanpa mendapatkan keadilan (Kusuma, 2018b). Dampak dari penggunaan kekerasan tersebut mengakibatkan banyaknya terjadi dugaan pelanggaran dalam proses penangkapan, dimana dalam kurun waktu 10 tahun (2006-2016), setidaknya ada 120 orang yang diduga sebagai teroris telah tewas ketika menjalani proses penangkapan, dan ada 40 orang menjadi korban salah penangkapan. Disamping itu, terdapat lebih dari 80 persen dari jumlah terduga teroris yang ditangkap telah mengalami tindakan kekerasan dan penyiksaan" (Almas, 2016).

Menurut komnas HAM, melalui pernyataan Wakil Ketuanya, Dianto Bachriadi menyatakan bahwa Densus 88 telah melakukan pelanggaran HAM dalam menjalankan tugas dan fungsinya dalam rangka penanganan terorisme. Adapun bentuk-bentuk pelanggaran yang dilakukan diantaranya: penghilangan nyawa oarang, melakukan penyiksaan, melakukan tindakan-tindakan yang kejam, perampasan hak beribadah, perampasan hak penggunaan penasihat hukum, perampasan hak komunikasi, perampasan hak beribadah, serta yang lainnya (Fajar, 2013).

Penggunaan pendekatan represif yang dilakukan oleh pemerintah Indonesia dalam hal ini melalui densus 88 dalam penanganan terorisme, memperlihatkan pemerintah Indonesia telah mengorbankan nilai HAM yang seharusnya dijamin keberadaannya (Haryadi, 2014). Indonesia yang memilih sistem demokrasi yang berlandaskan hukum dalam penyelenggaraan negara telah menangguhkan tugasnya dalam rangka menjamin penegakan HAM atas nama perang melawan ancaman terorisme. Hal itu menunjukkan bahwa kedudukan isu terorisme dipersepsikan telah memberikan ancaman terhadap keamanan nasional Indonesia. Untuk itu tulisan ini akan membahas terkait pembentukan persepsi pemerintah Indonesia dalam memaknai ancaman terorisme.

Para peneliti terdahulu sudah melakukan penelitian dengan tema serupa. Berbagai temuan dan kesimpulan sudah dipaparkan dalam karya ilmiah yang ditulis oleh para peneliti terdahulu. Misalnya Christian J. Tams, Endi Haryono, Hery Firmansyah, serta Erwin Yusup Sitorus yang telah menggunakan paradigma realisme dalam melihat kebijakan keamanan nasional dalam rangka melawan terorisme yang diambil oleh negara, yang hanya bertumpu pada faktor keamanan nasional yang bersifat materialisme (Tams, 2009) (Haryono, 2010) (Firmansyah, 2010) (Sitorus, 2016). Kemudian ada juga Ali Muhammad yang juga menggunakan paradigma realisme yang berpendapat bahwa kebijakan Indonesia dalam perang melawan terorisme telah dipengaruhi oleh kepentingan untuk perang melawan terorisme oleh negara-negara yang memiliki power, dalam hal ini Amerika Serikat dan Australia melalui bantuan-bantuan ataupun tekanantekanan terhadap pemerintah Indonesia (Muhammad, 2015).

Selain para peneliti yang menggunakan paradigma realis tersebut, ada juga beberapa peneliti terdahulu yang telah menggunakan paradigma konstruktivisme, di antaranya adalah Daniel Benjamin, Ahmad Zahid Hamidi, N.S. Jamwal, Sidratahta Mukhtar. Namun para peneliti tersebut hanya menggunakan pendekatan konstruktivisme untuk melakukan kritik atas kebijakan represif yang dianggap kurang tepat. Mereka lebih merekomendasikan untuk melawan terorisme dengan pendekatan soft power (Benjamin, 2008) (Hamidi, 2016) (Jamwal, 2003) (Mukhtar, 2016).

Sementara dalam tulisan ini ingin menjelaskan terkait adanya relasi antara ide atau gagasan yang kemudian menjadi persepsi dan pada akhirnya mempengaruhi pilihan sikap suatu negara. Dalam hal ini ide dan gagasan tentang terorisme telah mempengaruhi persepsi pemerintah Indonesia dalam memaknai ancaman terorisme yang kemudian menuntun pemerintah Indonesia untuk membuat kebijakan-kebijakan kontra terorisme yang bersifat represif dan melanggar HAM.

\section{METODE}

Tulisan ini bertujuan untuk melihat pengaruh dari dimensi ide atau gagasan terhadap pemerintah Indonesia dalam mempersepsikan ancaman terorisme, yang kemu-ian menuntun pemerintah Indonesia untuk membuat kebijakankebijakan yang bersifat represif dan cenderung melanggar HAM. Tulisan ini menggunakan metode kualitatif, dengan menggunakan paradigma konstruktivisme.

Dalam hal metodologi aliran konstriktivisme telah menjadi penengah atau berada di antara aliran positivist dan post-positivist. Aliran positivist berpndapat jika dunia ilmu sosial bisa dipelajari dengan menggunakan pendekatan objektif dan sifatnya baku seperti ilmu alam. Sementara post-positivist menolak hal tersebut dan berpendapat 
sebaliknya yaitu dunia ilmu sosial bisa dipelajari dengan cara-cara atau pendekatan yang tidak baku, dan sifatnya subjektif.

Untuk memahami dan menafsirkan makna intersubjektif, dalam paradigma konstruktivis menggunakan metode penelitian yang umum, diantaranya termasuk analisis wacana, penelusuran proses, silsilah, perbandingan terfokus terstruktur, wawancara, pengamatan partisipan, analisis konten, analisis konten kualitatif sumber utama (memoar, arsip), studi statistik. Menurut Finnemore dan Sikkink tidak ada metode atau desain penelitian tunggal di dalam paradigma konstruktivisme (Finnemore \& Sikkink, 2001).

Pernyataan tersebut menunjukkan bahwa posisi metodologi paradigma konstruktivisme berada di antara aliran positivisme dan post-positivisme. Dengan demikian kaum konstruktivisme bisa mengeksplorasi dunia sosial dengan lebih leluasa dan fleksibel.

Dalam upaya membangun obyektivitas dalam penelitian ini, data dikumpulkan melalui beberapa tahap. Pertama, studi dokumen terhadap naskah-naskah akademik atau dokumen resmi, ataupun sumber dari jurnalistik baik cetak ataupun daring, yang berkaitan dengan tema yang diangkat. Kemudian, data dalam tulisan ini juga didapatkan dari jurnal dan juga buku. Kedua, data dikumpulkan dengan mewawancarai beberapa pihak yang kompeten. Wawancara dilakukan terhadap beberapa pihak diantaranya, Deputi Kerjasama Internasional BNPT, anggota parlemen (anggota Komite Khusus Amandemen Undang-Undang Anti-terorisme), dan mantan kepala Badan Intelijen Strategis (BAIS). Setelah data terkumpul kemudian penulis melakukan analisis dan interpretasi terhadap data yang terkumpul untuk mendukung argumentasi yang dibangun. Tahap akhir yang dilakukan kemudian adalah penulisan laporan.

\section{HASIL DAN PEMBAHASAN}

\section{Wacana Tentang Terorisme Sebagai Ancaman di Dunia Internasional dan Pengaruhnya Terhadap Persepsi dan Sikap Pemerintah Indonesia: Sebuah Analisis}

Paradigma konstruktivisme dalam konteks studi keamanan, memiliki ciri khas tersendiri, di mana para pemikir paradigma ini tidak terlalu memfokuskan pemikirannya untuk menggali definisi dari keamanan, tetapi mereka lebih mencoba untuk memberikan makna terhadap apa yang dimaksud dengan keamanan itu sendiri. Para pemikir konstruktivis, memaknai keamanan sebagai "arena" negosiasi antar aktor. Hal tersebut dinyatakan oleh Matt McDonald sebagai berikut (McDonald, 2008):

that security is a site of negotiation (between the political leaders and domestic audiences in particular) and contestation (between different actors, elaborating different visions of "our" values and how "we" should act).

Pada intinya kaum konstruktivis membangun argumen bahwa ketika berbicara tentang keamanan maka realitas dari kemanan yang ada tidak dapat dipisahkan dari proses interaksi antar aktor yang kemudian membangun persepsi tentang keamanan itu sendiri. Dalam hal ini penerjemahan atas ancaman sangat dipengaruhi oleh persepsi dari masing-masing aktor dan juga atas konseptualisasi dari identitas dari masing-masing aktor. Ted Hopf telah memberikan ilustrasi bahwa tindakan suatu negara dalam konteks keamanan akan sangat dipengaruhi oleh persepsi yang terbangun dari interaksi sosial. Dalam hal ini persepsi dipengaruhi oleh identitas yang terbentuk. Jadi suatu negara akan mempersepsikan negara ataupun aktor lain sebagai "teman" atau "musuh", tergantung dari persepsi atas identitas-identitas dari masing-masing aktor yang terbentuk dari konstruksi sosial (Hopf, 1998).

Alexander Wendt juga telah menjelaskan bagaimana paradigma konstruktivis memahami ancaman yang sangat berbeda tentunya dari pemahaman pemikiran realis maupun liberal yang masih berbasis material. Misalnya saja memaknai kekuatan militer atau kekuatan persenjataan yang dimiliki oleh negara lain yang bagi kaum realis, kepemilikan senjata atau militer oleh negara lain itu secara material bisa dimaknai sebagai ancaman. Tetapi argumentasi tersebut dipatahkan oleh Alexander Wendt, bahwa instrumen material di dalam struktur sosial (sistem internasional) tidak akan bermakna apapun tanpa pengaruh suatu ide. Instrumen material dalam struktur hanyalah sebagai alat untuk penunjang aksi yang akan dilakukan oleh manusia. Kemudian untuk memudahkan pemahaman kita, Wendt memberikan suatu analogi yang menarik, bahwa 500 senjata nuklir yang dimiliki Inggris, dianggap lebih kecil pengaruh ancamanannya bagi Amerika Serikat juka dibandingkan dengan 5 senjata nuklir milik Korea Utara. Fenomena ini disebabkan karena, bagi Amerika Serikat, Inggris bukanlah musuh, melainkan dimaknai sebagai negara sahabat. Sementara Korea Utara, meskipun jumlah senjata nuklir yang dimilikinya jauh di bawah Inggris, tetapi akan dimaknai lebih mengancam bagi Amerika Serikat, karena Korea Utara tidak dikategorikan sebagai negara sahabat oleh Amerika Serikat (Wendt, 1995). Dari pernyataan tersebut dapat dilihat bahwa dalam berbicara mengenai isu keamanan, kaum konstruktivis lebih melihat pada variabel ide gagasan tentang persepsi terhadap aktor yang dianggap mengancam atau dianggap tidak mengancam, yang kemudian para sub-unit dalam suatu unit utuh akan saling mempengaruhi dalam memutuskan suatu tindakan dalam konteks mengamankan komunitas atau unit mereka 
secara utuh. Dalam bahasa lain jika unitnya adalah negara, maka ketika berbicara mengenai konteks keamanan maka di dalam negara akan terjadi pertarungan kepentingan (Interaksi yang sifatnya saling mempengaruhi tentang ide atau gagasan) antar aktor di dalam negara tersebut, untuk kemudian memutuskan suatu aksi untuk mengamankan negara. Jika dalam konteks unitnya adalah dunia internasional, makan negara-negara adalah sub unit (agen) yang akan saling mempengaruhi.

Tindakan dari aktor dipengaruhi oleh adanya persepsi atau pemaknaan terhadap suatu obyek atau aktor yang lain, sebagaimana diargumentasikan oleh Alexander Wendt bahwa:

"a fundamental principle of constructivist social theory is that people act toward objects, including other actors, on the basis of the meanings that the objects have for them." (Wendt, 1992)

Dengan jelas Wendt menyatakan bahwa tindakan aktor terhadap obyek atau aktor lain sangat ditentukan oleh persepsi atau pemakanaan terhadap obyek atau aktor lain tersebut, di mana persepsi atau pemaknaan tersebut terbentuk dari hasil konstruksi sosial.

Fenomena terorisme yang berkembang di dunia internasional saat ini, tidak dapat dipisahkan dengan adanya wacana yang dibentuk untuk membangun ide bersama terkait pemaknaan tentang terorisme. Sebagaimana telah dijelaskan oleh Rainer Hülsse dan Alexander Spencer bahwa terorisme dihasilkan dari konstruksi sosial. Lebih lanjut mereka menjelaskan bahwa realitas yang terjadi terkait terorisme merupakan hasil dari pembentukan wacana dari musuh para teroris tersebut yang kemudian membentuk motivasi, strategi, serta struktur organisasi dan juga tujuan dari para aktor teroris itu sendiri. Ilustrasi yang mudah untuk memahami pendekatan ini dapat dilihat dalam kasus konstruksi "metafora" Al-Qaeda oleh pers populer Jerman setelah serangan teroris di New York dan Washington pada tahun 2001, Madrid pada tahun 2004 dan London pada tahun 2005. Kasus-kasus tersebut pada awalnya dimaknai sebagai bentuk "perang" antar aktor dalam lingkup dunia internasional. Tetapi sejak tahun 2004 dan seterusnya telah muncul wacana yang kemudian secara pasti menggeser makna bahwa serangan Al-Qaeda yang semula dianggap sebagai bentuk perang menjadi sebuah tindakan yang dipandang sebagai kejahatan. Hal tersebut berdampak pada pembangunan makna tentang Al-Qaeda sebuah institusi kriminal yang saat ini kita kenal sebagai lembaga teroris. Pergeseran ini juga telah mengubah Al-Qaeda dari yang semula dianggap ancaman eksternal menjadi ancaman internal, yang mensyaratkan pergeseran praktek kontra-terorisme dari perang antar militer ke respon instrumen yudisial (Hülsse \& Spencer, 2008).
Fenomena tentang terorisme menjadi isu arus utama pasca serangan 11 September 2001 di gedung WTC oleh kelompok Al-Qaeda, yang kemudian memunculkan norma bersama dalam dunia internasional dalam memaknai terorisme.

Wacana perang melawan terorisme (war on terror) disosialisasikan untuk dijadikan norma internasional agar memiliki legitimasi dan memudahkan AS untuk mengajak negara-negara lain untuk melakukan perang melawan terorisme. Amerika Serikat telah menyebarkan nilai-nilai kepada dunia internasional dengan klaim bahwa nilai yang mereka tawarkan adalah nilai kebenaran universal. Misalnya saja dalam berbagai kesempatan presiden Bush mengaitkan perjuangan perang melawan terorisme sebagai perjuangan atas nilai kebebasan dan kemanusiaan. Selain itu pembangunan persepsi terkait siapa yang "baik" dan siapa yang "jahat" juga dilakukan untuk melegitimasi wacana perang melawan terorisme yang mereka perjuangkan. Dalam hal ini pihak-pihak yang turut serta dalam melakukan perang melawan terorisme adalah pihak yang baik dan kelompok seperti Al-Qaeda yang dijastifikasi sebagai kelompok teroris adalah pihak yang jahat (Kedang, 2017). Bahkan secara terbuka pasca peristiwa serangan 11 September, Bush telah mengaskan bahwa:

Our enemy is a radical network of terrorists, and every government that supports them. Our war on terror begins with al Qaeda, but it does not end there. It will not end until every terrorist group of global reach has been found, stopped and defeated ......This is not, however, just America's fight. And what is at stake is not just America's freedom. This is the world's fight. This is civilization's fight. This is the fight of all who believe in progress and pluralism, tolerance and freedom. We ask every nation to join us. We will ask, and we will need, the help of police forces, intelligence services, and banking systems around the world (Bush, 2001).

Dalam pernyataan Bush sebagai presiden AS waktu itu yang disampaikan pada 20 September 2001 telah menunjukkan bahwa Amerika Serikat telah menjastifikasi bahwa kelompok radikal dan kelompok teroris merupakan musuh bagi mereka. Bahkan negara yang memberikan dukungan kepada kelompok-kelompok yang telah dijustifikasi sebagai kelompok teroris maka juga akan dianggap sebagai musuh yang akan diperangi oleh Amerika Serikat. Selain itu, dengan mengatasnamakan nilai-nilai pluralisme, toleransi serta kebebasan (kemerdekaan), Amerika Serikat telah meminta kepada seluruh negara di dunia untuk turut serta dalam wacana perang melawan terorisme tersebut. tidak hanya itu, sebagai negara super power, AS telah melakukan share idea kepada komunitas internasional untuk kemudian dijadikan norma dalam bentuk konvensi 
atau perjanjian internasional yang menjadi instrumen hukum internasional di bawah naungan PBB yang mengatur persoalan terkait kegiatan perang melawan terorisme.

Sharing idea yang dilakukan oleh Amerika Serikat tersebut mampu mempengaruhi sistem pemikiran mayoritas masyarakat internasional dalam memaknai terorisme. Dengan kata lain pemahaman terhadap terorisme yang saat ini ada merupakan hasil dari sebuah share idea atau "framing" yang dilakukan Amerika Serikat (Bartolucci \& Gallo, 2015). Dalam hal ini Amerika Serikat adalah negara yang menjadi norms enterpreneurs, karena AS merupakan negara yang paling gencar menawarkan wacana "war on terror" kepada komunitas internasional. Melalui wacana tersebut kemudian Amerika Serikat secara masif mengkampanyekan kejahatan terorisme, dengan menggunakan momentum serangan 9 September 2001, sebagai simbol kejahatan terorisme (Kusuma, 2018a).

Secara terminologi, terorisme memiliki definisi yang beragam. Misalnya definisi dari Muladi yang mengutip dari Black Laws Dictionary (Muladi, 2002):

"tindak pidana terorisme merupakan tindakan yang melibatkan adanya unsur kekerasan atau sesuatu yang menimbulkan efek bahaya bagi kehidupan manusia yang melanggar hukum pidana, dan jelas dimaksudkan untuk mengintimidasi masyarakat sipil; mempengaruhi kebijakan pemerintah; mempengaruhi proses penyelenggaraan negara, dengan cara penculikan dan pembunuhan".

Selain itu ada beberapa definisi tentang terorisme yang berasal dari beberapa sumber yang menjelaskan tentang definisi dari terorisme, seperti yang telah dikutip oleh Irjen. Pol. Drs. Arsyad Mbai, yang mengutip beberapa definisi terorisme, diantaranya adalah (Mbai, 2003) :

a. Terrorism is an act carried out to achieve on in "human and corrupt objective and involving threat to security of mankind, and violation of rights acknowledge by religion and mankind" (Ayatullah Sheikh Muhammad AI Taskhiri).

b. Terrorism is the unlawful use of force or violence "against persons or property to intimidate or coerce a government, civilian populations, or any segment threat, in furtherance of political or social objective”(FBI).

Kemudian definisi terorisme menurut Walter Reich, sebagaimana dikutip oleh A.M. Hendropriono yang menyatakan bahwa terorisme adalah: suatu strategi kekerasan yang telah dirancang untuk mencapai atau meningkatkan hasil-hasil yang diinginkan, dengan cara menyebarkan atau menanamkan rasa ketakutan dikalangan masyarakat secara umum (Hendropriyono, 2009).
Selain itu dari sebuah forum curah gagasan (brainstorming) yang dihadiri oleh para akademisi, para profesional, para pakar, para pengamat politik serta para diplomat terkemuka yang diselenggarakan di kantor Menko Polkam pada tahun 2001, dapat disimpulkan mengenai pemahaman terkait teroisme yang diartikan sebagai suatu tindakan kekerasan yang dilakukan oleh sekelompok orang (yang biasa disebut sebagai ekstrimis, separatis, suku bangsa) sebagai pilihan jalan terakhir untuk memperoleh keadilan bagi mereka yang tidak dapat dicapai atau diperoleh melalui cara resmi atau jalan hukum"'(Mbai, 2003).

Terorisme umumnya dipahami untuk merujuk kepada tindakan kekerasan untuk menciptakan rasa takut yang meluas dalam mencapai tujuan politik atau ideologi tertentu. Jika merujuk pada pengertian terorisme secara material, maka pada dasarnya serangan yang dilakukan oleh Al-Qaeda tidak berbeda dengan perang-perang yang terjadi di dunia internasional selama ini. Bahkan jika kita bandingkan dengan operasi militer yang dilakukan oleh pasukan NATO (militer Perancis, Inggris dan AS) ketika melakukan serangan ke Libya dengan alasan intervensi untuk alasan kemanusiaan, meskipun negara-negara tersebut berdalih ketika melancarkan serangan hanya menargetkan pangkalan-pangkalan militer yang diduga sebagai loyalis Muammar Gaddafi, namun pada faktanya serangan yang dilakukan tersebut mengakibatkan ribuan masyarakat dari kalangan sipil telah menjadi korban dari serangan yang dilakukan oleh pesawat-pesawat tempur pasukan NATO (Indrawan, 2013).

Selain itu, invasi dan serangan Israel terhadap Palestina yang juga mengakibatkan banyaknya korban jiwa dari masyarakat sipil, serta menimbulkan ketakutan yang luar biasa bagi warga Palestina juga tidak dimaknai sebagai fenomena terorisme bagi sebagian masyarakat internasional, utamanya Amerika Serikat yang telah menggunakan standar ganda dalam memaknai terorisme (Fanani, 2011).

Antara fenomena serangan Al-Qaeda, serangan NATO terhadap Libya, Serangan Israel terhadap Palestina, jika ditinjau dari sisi materialisme, maka ketiganya sudah memenuhi unsur-unsur yang secara terminologi dapat diklasifikasikan kedalam aksi terorisme. Hanya saja yang terjadi adalah terkait ide dan persepsi terhadap fenomena-fenomena tersebut, yang menyebabkan dunia internasional memaknai tiga fenomena itu secara berbeda. Sehingga kesimpulannya masalah pemaknaan terorisme terletak pada level ide dan gagasan.

Sementara untuk dinamika perkembagan terkait tentang isu terorisme di Indonesia sendiri, sebenarnya sudah ada hampir sama usianya dengan usia negara Indonesia. Artinya sejak Indonesia merdeka tahun 1945, sudah ada gerakan-gerakan yang dapat dimasukkan 
kedalam kategori konsep terorisme secara terminologi. Bahkan perjuangan kemerdekaan Indonesia, boleh jadi bagi pemerintah kolonial Belanda bisa dikategorikan sebagai aksi teror dengan landasan nasionalis.

Peristiwa-peristiwayang padadasarnyamasukdalam kategori tindakan teror, sudah ada jauh sebelum Indonesia memiliki instrumen hukum tentang anti terorisme. Misalnya saja kasus Pemberontakan PKI Madiun (1948), Pemberontakan oleh DII/TII di Jawa Barat Tahun 1949, Angkatan Perang Ratu Adil atau APRA pada tahun 1950, Republik Maluku Selatan (1950), Pemberontakan DI/TII Sulawesi Selatan (1952), Pemberontakan DI/ TII Aceh (1953), Organisasi Papua Merdeka (1960-an), PRRI/PERMESTA (1958), Pemberontakan PKI (1965), peberontakan Fretelin's Timor-Timur (1975) (Muradi, 2012). Namun peristiwa-peristiwa tersebut ketika itu dipersepsikan sebagai kelompok gerakan pemberontakan oleh pemerintah Indonesia. Indonesia sendiri waktu itu belum memiliki instrumen hukum yang khusus untuk memaknai kelompok-kelompok tersebut sebagai kelompok terorisme.

Ancaman terkait isu terorisme, bagi pemerintah Indonesia memunculkan persepsi atau pemaknaan yang berbeda, jika dilihat dari waktu ke waktu. Perbedaan persepsi atau pemaknaan tersebut, terjadi akibat dari perbedaan jenis teror yang terjadi. Dalam melihat sikap dan cara pandang pemerintah Indonesia terhadap fenomena terorisme, dapat dibagi menjadi dua dimensi waktu. Yang pertama fenomena terorisme di era sebelum terjadinya peristiwa 9/11 dan fenomena terorisme di era pasca terjadinya peristiwa $9 / 11$.

Peristiwa-peristiwa teror yang terjadi di era sebelum tahun 2000-an dianggap sebagai suatu ancaman yang bersifat nasional. Karena memang waktu itu isu terorisme yang muncul adalah berupa aksi teror yang dilandasi alasan tuntutan untuk merdeka ataupun landasan ideologi yang dianggap oleh pemerintah Indonesia waktu itu bukan masuk kategori tindakan terorisme, melainkan dianggap sebagai tindakan pemberontakan dalam negeri yang mengancam keamanan nasional, dan bukan dilakukan oleh jaringan terorisme internasional seperti yang terjadi saat ini (Wuryandari, 2014).

Akibat dari persepsi dari pemerintah yang seperti itu, maka tidak heran jika penanganan terorisme di Indonesia di era sebelum terjadinya peristiwa 9/11 masih didominasi oleh pasukan militer dalam hal ini TNI, dan dilakukan secara domestik dan tidak melakukan kerjasama dengan negara lain, karena masalah tersebut dianggap sebagai masalah domestik (urusan dalam negeri).

Persepsi Indonesia dalam melihat isu terorisme mulai berubah di awal era 2000-an. Hal tersebut terjadi seiring dengan perubahan konstelasi politik internasional yang juga dipengaruhi oleh isu terorisme internasional yang menjadi isu aktual. Isu terorisme menjadi isu penting di dunia internasional sejak terjadinya peristiwa teror yang dialami Amerika Serikat (9/11).

Pasca terjadinya serangan terhadap gedung WTC yang terjadi pada 11 September tahun 2001, Amerika Serikat memunculkan pemahaman atau pemaknaan baru tentang terorisme, termasuk pemahaman bagi pemerintah Indonesia. Dari yang awalnya terorisme dilihat sebagai kejahatan luar biasa yang sifatnya nasionalistik dan dalam konteks teritorial tertentu, berubah menjadi tindakan kejahatan yang beririsan dengan karakter ideologi tertentu serta memiliki ikatan dengan agama, serta sifatnya melintasi batas negara. Eksistensi dari hegemoni Amerika Serikat terhadap peta politik internasional juga semakin terasa pasca serangan 9/11. Kebijakan AS terkait Global War om Terror telah menuntut dukungan dari dunia internasional. Amerika Serikat seolah-olah hanya memberikan dua pilihan bagi komunitas internasional yaitu bergabung dengan AS untuk memerangi terorisme, atau menjadi bagian dari terorisme dan menjadi musuh dari AS. Kebijakan tersebut langsung direspon oleh pemerintah Indonesia yang waktu itu di bawah kepemimpinan Megawati dengan sikapnya yang mendukung penuh dan memilih menjadi bagian dari AS untuk memerangi terorisme (Wuryandari, 2014).

Serangan terhadap gedung WTC tersebut ditambah adanya beberapa peristiwa yang terjadi di dalam negeri yang kemudian dimaknai sebagai tindakan terorisme telah merubah paradigma pemerintah Indonesia dalam memandang fenomena terorisme. Pemerintah Indonesia kemudian memiliki persepsi atau pemaknaan terhadap terorisme yang kemudian dianggap sebagai ancaman yang nyata terhadap keamanan nasional. Ketika penulis mengajukan pertanyaan kepada mantan kepala Badan Intelijen Strategis yaitu Soleman B. Ponto terkait pemaknaan terhadap ancaman dari terorisme bagi Indonesia dia menjelaskan bahwa pemerintah Indonesia memiliki persepsi bahwa terorisme dimaknai sebagai ancaman fisik terutama ancaman bagi keselamatan warga negara Indonesia yang dalam banyak kasus telah menjadi korban dari aksi para teroris (Ponto, 2018). Isu terorisme yang berkembang, baik dalam level internasional maupun dalam level nasional tersebut telah menjadi titik perubahan yang dilakukan oleh pemerintah Indoneisa dalam konteks memaknai dan menghadapi isu terorisme baik dalam level nasional maupun internasional.

Merujuk pada pandangan filosofis kaum konstruktivisme, maka dapat dilihat bahwa isu ancaman terorisme terhadap keamanan baik pada level internasional ataupun nasional tergantung dari ide yang dimunculkan untuk memaknai dari fenomena terorisme itu sendiri. Penjelasan sederhananya adalah, bahwa fenomena yang terjadi yang saat ini kita klasifikasikan sebagai fenomena terorisme 
sejatinya tergantung dari ide dalam melihat fenomena tersebut karena memang dari awal pengertian terkait terorisme memiliki banyak arti. Dalam hal ini bisa jadi fenomena yang dipandang oleh seseorang sebagai fenomena terorisme, namun ternyata dari sudut pandang orang lain fenomena tersebut dimaknai sebagai perjuangan kemerdekaan.

Sebagai contoh, jika orang Indonesia ditanya terkait siapa Diponegoro, maka mayoritas akan menjawab dia adalah seorang pahlawan pejuang kemerdekaan. Tetapi jika kita bertanya pada orang Belanda bisa jadi mereka menjawab bahwa Diponegoro adalah seorang penjahat perang atau bahkan mereka memaknai Diponegoro sebagai teroris. Karena strategi perang gerilya yang dilakukan oleh Diponegoro dalam menghadapi Belanda, merupakan salah satu strategi dalam perang asimetris yang memiliki esensi yang sama dengan strategi teror yang juga menjadi salah satu pilihan strategi dalam perang asimetris.

Perang asimetris adalah perang yang melibatkan antara dua belah pihak atau lebih yang memiliki sumber daya atau kekuatan yang berbeda, sehingga seringkali dalam perang asimetris muncul cara-cara atau metodemetode yang baru dan sama sekali berbeda dengan strategi perang konvensional. Hal ini biasanya dilakukan oleh pihak yang lebih lemah untuk mengimbangi kekuatan lawannya yang lebih besar (Sudhir, 2008). Strategi perang gerilya atau strategi teror merupakan pilihan-pilahan yang bersifat unconvensional yang dipilih oleh pihak yang lemah untuk mengimbangi kekuatan lawannya.

Dalam melihat dan memaknai fenomena serangan Al-Qaeda terhadap AS, serangan NATO terhadap Libya, Serangan Israel kepada Palestina, bahkan terkait strategi perlawanan Diponegoro kepada Belanda, tergantung dari ide atau gagasan dalam memaknai fenomena-fenomena tersebut. Itu artinya suatu tindakan itu bermakna sebagai tindakan terorisme atau bukan, tergantung dari ide dalam melihat tindakan tersebut. Sementara ide untuk memaknai terorisme sebagai ancaman, dapat disebarluaskan dengan wacana yang dibangun untuk mengkonstruksi ide yang ada pada masyarakat secara umum.

\section{SIMPULAN}

Fenomena yang masuk dalam klasifikasi tindakan terorisme, sudah ada di Indonesia jauh sebelum pemerintah Indonesia memiliki instrumen kontra terorisme. Beberapa peristiwa seperti Pemberontakan PKI Madiun (1948), Pemberontakan yang dilakukan oleh DII/TII di Jawa Barat tahun 1949, Angkatan Perang Ratu Adil atau APRA tahun 1950, Republik Maluku Selatan (1950), Pemberontakan DI/TII Sulawesi Selatan (1952), Pemberontakan DI/ TII Aceh (1953), Organisasi Papua Merdeka (1960an), PRRI/PERMESTA (1958), Pemberontakan PKI
(1965), pemberontakan Fretelin's Timor-Timur (1975) merupakan peristiwa-peristiwa yang dapat dikategorikan ke dalam tindakan terorisme. Pemerintah Indonesia banyak menggunakan kekuatan militer ketika menangani peristiwa-peristiwa tersebut.

Pada waktu itu pemerintah Indonesia mempersespsikan peristiwa-peristiwa tersebut sebagai perstiwa pemberontakan dan ditangani secara mandiri. Karena waktu itu segala bentuk pemberontakan yang terjadi dianggap sebagai ancaman nasional dan menjadi urusan dalam negeri. Namun setelah tahun 2000-an, tepatnya pasca terjadinya peristiwa serangan di gedung WTC di Amerika Serikat, isu terorisme menjadi isu yang kuat dalam pergaulan di dunia internasional. Berkembangnya isu terorisme di dunia internasional tersebut ternyata memberikan dampak terhadap kebijakan keamanan di Indonesia. Pasca peristiwa 9/11 tersebut, pemerintah Indonesia mengeluarkan kebijakan-kebijakan dan membuat instrumen kontra terorisme. Terorisme yang dipersepsikan sebagai tindakan kejahatan luar biasa dan memberikan ancaman dalam pergaulan internasional, telah mempengaruhi pemerintah Indonesia. Ide tentang terorisme di dunia internasional tersebut membentuk persespsi pemerintah Indonesia hingga akhirnya pemerintah Indonesia membuat kebijakan yang represif dan cenderung melanggar HAM. Dapat disimpulkan bahwa ide (persepsi) pemerintah Indonesia yang terbentuk dari konstruksi sosial (pergaulan internasional) menjadi pengaruh yang cukup besar ditunjukkan dengan adanya perubahan cara atau strategi untuk menghadapi peristiwa yang cenderung memiliki tipe yang sama baik pada masa sebelum tahun 2000-an dan setelah tahun 2000-an. Perubahan ide (persepsi) yang kemudian menuntun pemerintah Indonesia dalam mengambil sikap dalam menghadapi terorisme.

Pemerintah Indonesia harus lebih teliti dalam memaknai terorisme itu sendiri. sehingga suatu tindakan atau kelompok yang dimaknai sebagai teroris, harusnya adalah tindakan atau kelompok yang benar-benar memenuhi kriteria sebagai teroris, dan yang benar-benar memberikan ancaman terhadap keamanan Indonesia secara umum. Selain itu penegakan hukum anti terorisme yang sudah dibuat di Indonesia harus bisa dijalankan dengan prinsipprinsip keadilan, dan tidak ada pihak-pihak tertentu yang merasa diperlakukan tidak adil.

\section{DAFTAR PUSTAKA}

Almas, P. (2016, March). Kinerja Densus 88 Dinilai Bisa Gagalkan Upaya Kontra Terorisme _ Republika Online. Republika.co.id. Retrieved from http:// nasional.republika.co.id/berita/nasional/ hukum/16/03/29/o4svuw361-kinerja-densus-88dinilai-bisa-gagalkan-upaya-kontra-terorisme 
Bartolucci, V., \& Gallo, G. (2015). Terrorism, System Thinking and Critical Discourse Analysis. Systems Research and Behavioral Science, 32, (1), 15-27. https://doi.org/10.1002/sres.2206

Benjamin, D. (2008). Strategic Counterterrorism. Foreign Policy at Brookings, 7, (October), 1-21.

Bush, G. W. (2001). Address to a Joint Session of Congress and the American People. Retrieved July 11, 2018, from https://2001-2009.state.gov/coalition/cr/ $\mathrm{rm} / 2001 / 5025 . h t m$

Fajar. (2013, November 26). Ini 10 Tindakan Pelanggaran Densus 88 Menurut Komnas HAM - Kiblat. Kiblat.net. Retrieved from https://www.kiblat. net/2013/11/26/ini-10-tindakan-pelanggaran-hamdensus-88-menurut-komnas-ham/

Fanani, A. F. (2011). The global war on terror, American foreign policy, and its impact on Islam and Muslim societies. Indonesian Journal of Islam and Muslim Societies, 1, (2), 205-255. https://doi. org/10.18326/ijims.v1i2.205-255

Finnemore, M., \& Sikkink, K. (2001). TAKING S TOCK: The Constructivist Research Program in International Relations and Comparative Politics. Annual Reviews of Political Science, 4, (June), 391-416. https://doi.org/10.1146/annurev. polisci.4.1.391

Firmansyah, H. (2010). Upaya Penanggulangan Tindak Pidana Terorisme di Indonesia. Mimbar Hukum, 23, (2), 237-429. https://doi.org/https://doi. org/10.22146/jmh.16193

Hamidi, A. Z. (2016). Malaysia's Policy On Counter Terrorism And Deradicalisation Strategy. Journal of Public Security and Safety, 6, (2), 1-19.

Haryadi, D. (2014). Pemberantasan Terorisme Berorientasi HAM, 42, (2), 247-254.

Haryono, E. (2010). Kebijakan Anti-Terorisme Indonesia: Dilema Demokrasi dan Represi. Jurnal Ilmu Sosial Dan Ilmu Politik, 14, (2), 229-246.

Hendropriyono, A.M. (2009). Terorisme Fundamentalis Kristen, Yahudi, Islam. jakarta: Kompas.

Hopf, T. (1998). The Promise of Constructivism in International Relations Theory. International Security, 23, (1), 171-200. https://doi. org/10.2307/2539267

Hülsse, R., \& Spencer, A. (2008). The Metaphor of Terror: Terrorism Studies and the Constructivist Turn. Security Dialogue, 39, (6), 571-592. https://doi. org/10.1177/0967010608098210
Indrawan, J. (2013). Legalitas dan Motivasi NATO ( North Atlantic Treaty Organization ) dalam Melakukan Intervensi Kemanusiaan di Libya. Jurnal Kajian Wilayah, 4, (2), 127-149.

Jamwal, N. S. (2003). Counter Terrorism Strategy. Strategic Analysis, 27,(1), 1-29. Retrieved from https://idsa. in/system/files/strategicanalysis_jamwal_0303.pdf

Kedang, A. Y. (2017). Internasionalisasi dan Internalisasi Wacana War on Terror. Sosial Politik, 3, (2), 2142. https://doi.org/https://doi.org/10.22219/sospol. v3i2.4883

Kusuma, A. J. (2018a). Isu Terorisme: Dalam Dimensi Material Dan Imaterial. (Danang Trijayanto and Iqbal Aidar Idrus, Ed.). Jakarta: Universitas 17 Agustus 1945 Jakarta.

Kusuma, A. J. (2018b). The Allegation of Human Rights Violation in the Process of Counter-Terrorism Acts in Indonesia by Densus 88 Force. Advanced Science Letters, 24, (5), 3394-3398. https://doi. org/https://doi.org/10.1166/asl.2018.11384

Mbai, A. (2003). Terorisme dan penanggulangannya. In Seminar Tentang Penegakan Hukum Terhadap Terorisme (p. 124). Bandung: BPHN Departernen Kehakiman dan HAM bekerjasama dengan Fakultas Hukum Universitas Padjadjaran.

McDonald, M. (2008). Security Studieas An Intriduction. In P. D. Williams (Ed.), Security Studieas An Intriduction (pp. 59-73). New York: Routledge.

Muhammad, A. (2015). Indonesia's Experience In The War on Terror. Yogyakarta: The Phinisi Press.

Muhtar, Z. (2014). Eksistensi Densus 88: Analisis Evaluasi Dan Solusi Terkait Wacana Pembubaran Densus 88. SUPREMASI HUKUM, 3. (1), 123-138.

Mukhtar, S. (2016). Strategi Pemerintah Indonesia Menghadapi Terorisme Dalam Era Demokratisasi. Reformasi, 6, (2), 143-153.

Muladi. (2002). Demokrasi Hak Asasi Manusia dan Reformasi Hukum di Indoesnaia. jakarta: Habibie Center.

Muradi. (2012). DENSUS 88 AT Konflik, Teror dan Politik. Bandung: Dian Cipta.

Ponto, S. B. (2018). Public Discussion and Personal Interview to Soleman B. Ponto (Head of Strategic Intelligence Agency). jakarta: Imparsial.

Sitorus, E. Y. (2016). The Philippine National Security Policy In The Counter Terrorism. Jurnal Prodi Peperangan Asimetris, 3, (2), 25-38. 
Sudhir, M. R. (2008). Asymmetric War: A Conceptual Understanding. Journal of the Center for Land Warfare Studies, 58-66. Retrieved from https:// www.claws.in/images/journals_doc/742067376 MBSushir.pdf

Tams, C. J. (2009). The Use of Force against Terrorists. The European Journal of International Law, 20, (2), 359-397. https://doi.org/10.1093/ejil/chp031

Wendt, A. (1992). Anarchy is What States Make of It: The Social Construction of Power Politics.
International Organization, 46, (2). https://doi. org/10.1017/S0020818300027764

Wendt, A. (1995). Constructing International Politics. International Security, 20, (1), 71-81. https://doi. org/10.2307/2539217

Wuryandari, G. (2014). Politik Luar Negeri Indonesia Dalam Menghadapi Isu Terorisme Internasional. Jurnal Penelitian Politik, 11, (2), 71-83. https:// doi.org/https://doi.org/10.14203/jpp.v11i2.202 